\title{
Purification and Properties of Glucosyltransferase Produced by Streptococcus salivarius HHT
}

\author{
Yoichi Tsumuraya* and Akira MisaKi** \\ Department of Food and Nutrition, Faculty of Science of Living, \\ Osaka City University, \\ Sugimoto-cho, Sumiyoshi, Osaka 558, Japan
}

Received February 5, 1981

\begin{abstract}
Glucosyltransferase produced by Streptococcus salivarius HHT was purified from the culture filtrate, and its enzymic properties were examined. The enzyme was specific to sucrose $(\mathrm{Km} 7.2 \mathrm{~mm})$, and formed a water-insoluble $\alpha$-D-glucan consisting of a high proportion of $(1 \rightarrow 3)$ - $\alpha$-D-glucosidic linkage $(90 \%)$ together with small proportions of $(1 \rightarrow 6)$ - and $(1 \rightarrow 4)-\alpha$-D-glucosidic linkages. The optimum $\mathrm{pH}$ and temperature of the enzyme activity were 5.8 and $40^{\circ} \mathrm{C}$, respectively. The enzyme activity and yield of the water-insoluble glucan were stimulated in the presence of dextran. The addition of low molecular weight oligosaccharides, such as maltose and isomaltose, inhibited the production of the water-insoluble glucan with the concomitant formation of several oligosaccharides, i.e., $O-\alpha$-D-glucopyranosyl-( $1 \rightarrow 6)-O-\alpha$-D-glucopyranosyl-( $1 \rightarrow 4)$-D-glucopyranose (panose), $O$ - $\alpha$-D-glucopyranosyl-( $1 \rightarrow 3)-O$ - $\alpha$-D-glucopyranosyl-( $1 \rightarrow 4)$-D-glucopyranose, maltotriose, and $O$ - $\alpha$-D-glucopyranosyl-( $1 \rightarrow 6)$ - $O$ - $\alpha$-D-glucopyranosyl-( $1 \rightarrow 6)-O$ - $\alpha$-D-glucopyranosyl-( $1 \rightarrow 4)$-D-glucopyranose.
\end{abstract}

Glucosyltransferases produced by several cariogenic Streptococci have been studied, particularly, in relation to the formation of water-insoluble $\alpha$-D-glucans which may induce dental caries. Some glucosyltransferases were purified, and their enzymic properties and the structures of the water-insoluble glucans were intensively studied. ${ }^{1 \sim 6)}$ In the previous work, ${ }^{7)}$ we elucidated a possible structure for the water-insoluble glucan produced on the cultivation of Streptococcus salivarius HHT, a weak cariogenic strain originally isolated by Jablon et al. ${ }^{8)}$ The purified glucan had a nonadherent property and consisted of a high proportion $(80 \%)$ or $(1 \rightarrow 3)-\alpha-D$-glucosidic linkage together with small proportions of $(1 \rightarrow 6)$ - and $(1 \rightarrow 4)$-D-glucosidic linkages. The proportion of $(1 \rightarrow 3)$ - $\alpha$-D-glucosidic linkage in the HHT glucan is higher than that of hitherto known glucans of $S$. salivarius, such as strain

* Present address: Department of Biochemistry, Faculty of Science, Saitama University, Urawa 338, Japan.

** To whom requests for reprints should be sent.
ATCC 13419. ${ }^{6}$ Since the high proportion of $(1 \rightarrow 3)$-linked D-glucose residues in the glucan would be formed from sucrose by the glucosyltransferase action, highly specific to the $(1 \rightarrow 3)$ D-glucosidic linkage, the glucosyltransferase of $S$. salivarius HHT was purified and its enzymic properties were studied.

\section{EXPERIMENTAL}

Materials. Dextrans (molecular weight $1 \times 10^{4}, 1.1 \times 10^{5}$ and $3 \times 10^{6}$ ) and isomaltose were donated by Meito Sangyo Co. (Nagoya). Dextran specimens were prepared by fractionation of the mild acid hydrolyzate of the dextran produced on the cultivation of Leuconostoc mesenteroides $\mathrm{N} 4$, a strain used for industrial production in Japan. Cellulose (CF 11) and soluble starch were purchased from Whatman Ltd., and Kishida Chemical Co. (Osaka), respectively. $O$ - $\alpha$-D-glucopyranosyl- $(1 \rightarrow 4)-O-\alpha-$ D-glucopyranosyl- $(1 \rightarrow 2)-O-\beta$-D-fructofuranoside $\quad\left(4^{\mathrm{G}}-\alpha\right.$ glucosylsucrose), $\quad O$ - $\alpha$-D-glucopyranosyl-( $1 \rightarrow 4)-O-\alpha$-Dglucopyranosyl-( $1 \rightarrow 4)$ - $O$ - $\alpha$-D-glucopyranosyl- $\quad(1 \rightarrow 2)-O$ $\beta$-D-fructofuranoside $\quad\left(4^{\mathrm{G}}-\alpha\right.$-maltosylsucrose $)$, maltose, maltotriose and pullulan were donated by Hayashibara Biochemical Laboratory Inc. (Okayama), and former two being prepared from sucrose and starch by the action of cyclodextrin glucosyltransferase from Bacillus megaterium 
or Bacillus macerans. ${ }^{9)}$ Panose was kindly donated by Dr. Y. Tsujisaka. $O$ - $\alpha$-D-glucopyranosyl-( $1 \rightarrow 3)-O-\alpha$-D-glucopyranosyl-( $1 \rightarrow 4)$-D-glucopyranose was prepared by the enzymic degradation of elsinan. ${ }^{10)}$ Other sugar specimens were obtained from commercial sources. Saccharomyces cerevisiae $\alpha$-D-glucosidase (type I) and Rhizopus niveus glucoamylase (twice crystallized) were purchased from Sigma Chemical Co., and Seikagaku Kogyo Co. (Tokyo), respectively.

Enzyme production. S. salivarius HHT was grown in Trypticase soy broth (Baltimore Biochemical Lab.), pH 7.2 , for $24 \mathrm{hr}$ at $37^{\circ} \mathrm{C}$. All purification steps for the enzyme were carried out at $0 \sim 4^{\circ} \mathrm{C}$.

Assay of the enzyme activity. The activity of glucosyltransferase was assayed by incubation $(0.2 \mathrm{ml})$ of the appropriately diluted enzyme solution, $25 \mathrm{~mm}$ sucrose and $0.05 \mathrm{M}$ phosphate buffer, $\mathrm{pH} 5.8$, for $15 \mathrm{~min}$ at $37^{\circ} \mathrm{C}$. The reaction was stopped by addition of alkaline-copper reagent, ${ }^{11)}$ and the reducing sugar was determined. One unit of the enzyme was defined as the amount which liberated one $\mu \mathrm{mol}$ of reducing sugar equivalent per min, expressed as fructose. The activity of fructosyltransferase was assayed in the same manner and by examination of the sugar component of the water-soluble polysaccharide produced by the enzyme action. The activity of levan hydrolase was measured by incubation $(0.2 \mathrm{ml})$ of the enzyme solution with $0.2 \%$ of levan, obtained from the culture filtrate of this organism, ${ }^{7)}$ in $0.05 \mathrm{M}$ phosphate buffer, $\mathrm{pH} 5.8$, for $15 \mathrm{~min}$ at $37^{\circ} \mathrm{C}$, after which the reducing sugar was determined.

Production of polysaccharides. The extracellular waterinsoluble $\alpha$-D-glucan was produced by cultivation of $S$. salivarius HHT in Trypticase soy broth supplemented with $5 \%$ sucrose, $\mathrm{pH} 7.2$, for $24 \mathrm{hr}$ at $37^{\circ} \mathrm{C}$. The glucan was purified from the culture broth by extraction with $1 \mathrm{M}$ sodium hydroxide, followed by neutralization of the extract according to the previously reported procedure. ${ }^{7)}$ The extracellular water-soluble levan produced in the same culture ${ }^{7,12)}$ was purified by repeated ethanol precipitations. The enzymically synthesized water-insoluble glucan was produced by incubation of cell-free enzyme preparations with sucrose at $37^{\circ} \mathrm{C}$ under various conditions in the presence of toluene. The glucan in the reaction mixture was purified by the same procedure as that for the extracellular glucan.

General analytical methods. Total carbohydrate was estimated by the phenol-sulfuric acid method. ${ }^{13)}$ The reducing sugar was measured by the method of NelsonSomogyi. ${ }^{11)}$ Degrees of polymerization $(D P)$ of oligosaccharides were determined by the method of Timell. ${ }^{14)}$ Protein was determined by the method of Lowry et al. ${ }^{15)}$ with crystalline bovine serum albumin (Sigma Chemical Co.) as a standard, and by the absorbance at $280 \mathrm{~nm}$.
Deionization of a sugar solution was done by passage through a short column of Amberlite IR-120B( $\left.\mathrm{H}^{+}\right)$or a column of mixed resins, Amberlite IR-120B $\left(\mathrm{H}^{+}\right)$and IRA-400 $\left(\mathrm{OH}^{-}\right)$. All evaporations were conducted at below $40^{\circ} \mathrm{C}$.

Paper chromatography was carried out on Whatman $3 \mathrm{MM}$ or Toyo-roshi No. 50 paper with a solvent system of 1-butanol-pyridine-water, $6: 4: 3$, v/v. Sugars on the paper were detected with alkaline silver nitrate reagent. ${ }^{16)}$ The detection of non-reducing sugars on the paper was carried out by spraying $1 \%$ sodium metaperiodate in $50 \%$ aqueous acetone ${ }^{17)}$ before treatment with the silver nitrate reagent.

Paper electrophoresis was performed on Whatman $3 \mathrm{MM}$ paper with $0.1 \mathrm{M}$ borate buffer, $\mathrm{pH} 9.2$, at $15 \mathrm{v} / \mathrm{cm}$. The sugars on the paper were detected with silver nitrate reagent.

Gas liquid chromatography (GLC) of the methyl sugar components was carried out with a Hitachi Gas Chromatograph Model 163, fitted with a flame-ionization detector, using a column of $3 \%$ ECNSS-M on Gaschrom $\mathrm{Q}(2 \mathrm{~m})$ at $180^{\circ} \mathrm{C}$ after conversion to the alditol acetates, and also with a column of $15 \%$ butanediol succinate polyester on Neosorb $\mathrm{N}(1 \mathrm{~m})$ at $175^{\circ} \mathrm{C}$, after conversion to the corresponding methyl glucosides.

High performance liquid chromatography (HPLC) was done with a Hitachi Liquid Chromatograph Model 635, fitted with a refractive-index indicator, using a column $(8 \times 500 \mathrm{~mm})$ of Hitachi cation-exchanger resin 2618 with water as carrier at $25^{\circ} \mathrm{C}$.

Methylation. Methylation of the water-insoluble glucan was carried out according to the method of Hakomori. ${ }^{18)}$ The glucan $(10 \sim 20 \mathrm{mg})$ was dissolved in dimethyl sulfoxide $(2 \mathrm{ml})$ with the aid of ultrasonication under a nitogen atmosphere, and was then treated with methylsulfinyl carbanion $(0.5 \mathrm{ml})$ for $4 \mathrm{hr}$ at room temperature, followed by treatment with methyl iodide $(1.5 \mathrm{ml})$ for $1.5 \mathrm{hr}$ at $20^{\circ} \mathrm{C}$. The methylated glucan in the reaction mixture was dialyzed against distilled water, evaporated, and dried in vacuo. After repeating the methylation two more times, a portion of the fully methylated glucan was hydrolyzed by heating with $90 \%$ formic acid $(0.5 \mathrm{ml})$ for $12 \mathrm{hr}$ at $100^{\circ} \mathrm{C}$, followed by heating with $2 \mathrm{M}$ trifluoroacetic acid $(0.5 \mathrm{ml})$ for $3 \mathrm{hr}$ at $100^{\circ} \mathrm{C}$. The mixture of the methylated sugars was reduced with sodium borohydride at room temperature and the corresponding alditols were acetylated by heating with $1: 1$ pyridine-acetic anhydride $(0.2 \mathrm{ml})$ for $2 \mathrm{hr}$ at $100^{\circ} \mathrm{C}$, and analyzed by GLC. Another portion of the methylated glucan was methanolyzed with $3 \%$ methanolic hydrogen chloride $(0.5 \mathrm{ml})$ for $18 \mathrm{hr}$ at $90^{\circ} \mathrm{C}$. The methanolyzate was neutralized with silver carbonate, and the mixture of the methyl glucosides was analyzed by GLC.

The oligosaccharide $(1 \sim 5 \mathrm{mg})$ was methylated in the same manner, and the methylated oligosaccharide was extracted with chloroform and concentrated to a syrup. 


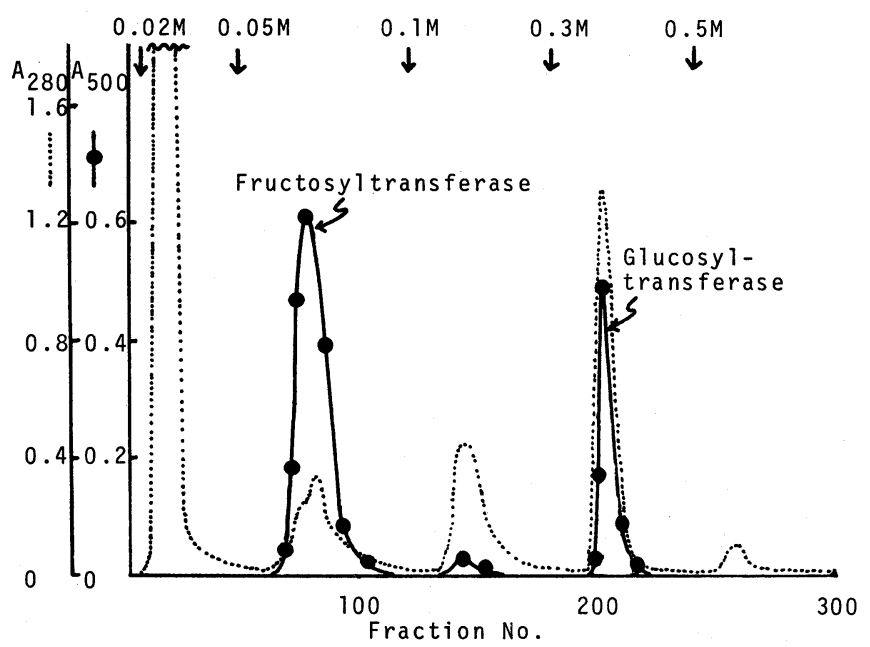

Fig. 1. Elution Profile of the Enzyme Preparation after Ammonium Sulfate Fractionation on a Column $(3.5 \times 15 \mathrm{~cm})$ of Hydroxylapatite.

Stepwise elution with $0.02,0.05,0.1,0.3$ and $0.5 \mathrm{~m}$ phosphate buffer, $\mathrm{pH} 6.8$, as indicated by arrows, was done to elute the enzyme. Fractions of $13 \mathrm{ml}$ each were collected. ---, protein;

The syrup was dissolved in a small volume of chloroformmethanol $(2: 1, \mathrm{v} / \mathrm{v})$ and applied to a column $(1 \times 20 \mathrm{~cm})$ of Sephadex LH-20, and the methylated product was eluted with the same solvent. The eluates containing the methylated oligosaccharide were combined and concentrated to dryness. A portion of the methylated product was hydrolyzed by heating with $3 \mathrm{M}$ trifluoroacetic acid $(0.5 \mathrm{ml})$ for $7 \mathrm{hr}$ at $100^{\circ} \mathrm{C}$ and the mixture of the methyl sugar components was analyzed by GLC after conversion to the alditol acetates. Another portion was methanolyzed and analyzed by GLC.

Enzymic hydrolysis and partial acid hydrolysis of oligosaccharides. The oligosaccharide $(1 \mathrm{mg})$ was incubated with $\alpha$-D-glucosidase $(50 \mu \mathrm{g})$ in $0.05 \mathrm{M}$ phosphate buffer $(0.1 \mathrm{ml}), \mathrm{pH} 6.8$, at $37^{\circ} \mathrm{C}$. At appropriate time-intervals, portions were withdrawn, inactivated by heating, and the products were examined by paper chromatography. The oligosaccharide ( $1 \mathrm{mg}$ ) was also incubated with glucoamylase $(45 \mu \mathrm{g})$ in $0.05 \mathrm{M}$ acetate buffer $(0.15 \mathrm{ml}), \mathrm{pH}$ 4.5 , at $37^{\circ} \mathrm{C}$, and the hydrolysis products were examined by paper chromatography.

The oligosaccharide $(4.4 \mathrm{mg})$ was hydrolyzed with 0.1 or $0.8 \mathrm{M}$ trifluoroacetic acid $(0.13 \mathrm{ml})$, for 5 to $120 \mathrm{~min}$ at $100^{\circ} \mathrm{C}$. The hydrolysis products at time intervals were examined in the same manner.

\section{RESULTS}

\section{Purification of glucosyltransferase}

$S$. salivarius HHT was cultivated in Trypticase soy broth. The culture filtrate (7.5 liter) was brought to $50 \%$ saturation with ammonium sulfate in the presence of $0.05 \%$ egg albumin, which may enable stabilization of the enzyme and give a higher recovery of the enzyme activity. The precipitate was dissolved in a small volume of $0.02 \mathrm{M}$ phosphate buffer, $\mathrm{pH}$ 6.8, and dialyzed against the same buffer. The solution was chromatographed on a hydroxylapatite column (Fig. 1). The fraction corresponding to the first peak (tube numbers $68 \sim 102$ ) was found to contain fructosyltransferase, which produced only watersoluble fructan (levan) when incubated with sucrose. The third peak (tubes $198 \sim 215$ ) contained the glucosyltransferase activity, producing only a water-insoluble glucan from sucrose. The second peak (tubes $145 \sim 155$ ) also showed a small amount of glucosyltransferase activity, which produces a water-insoluble glucan having similar properties to those of the glucan produced by the enzyme that emerged as the third peak, though this fraction was not studied further. Since the levan hydrolase activity was distributed over all fractions, the glucosyltransferase fraction was applied to a DEAE Bio-Gel A column (Bio-Rad Laboratories), as shown in Fig. 2. The fraction containing glucosyltransferase activity collected 


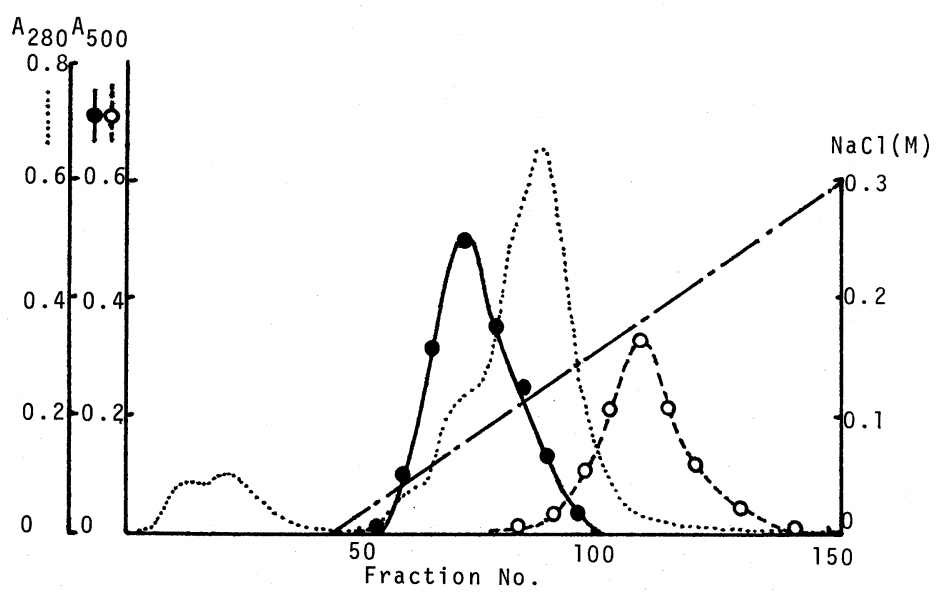

Fig. 2. Column Chromatographic Profile of the Glucosyltransferase Fraction on a DEAE Bio-Gel A Column.

The enzyme in $0.02 \mathrm{M}$ phosphate buffer, $\mathrm{pH} 6.8$, was placed on a column $(2.0 \times 27 \mathrm{~cm})$ of DEAE Bio-Gel A. After elution with the same buffer, a linear gradient of 0 to $0.3 \mathrm{M}$ sodium chloride in the buffer was used to elute the enzyme. Fractions of $8 \mathrm{ml}$ each were collected. ---, protein; - - enzyme activity; $\bigcirc--\bigcirc$, levan hydrolase activity.

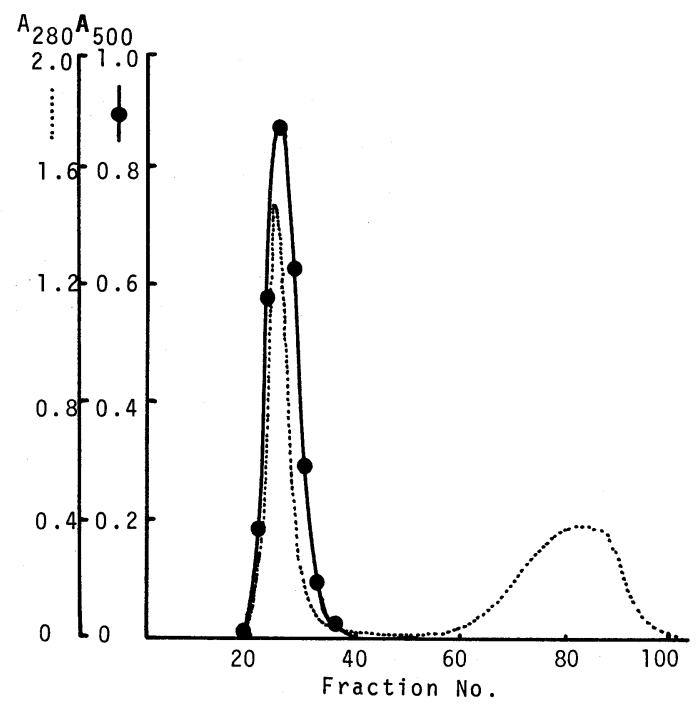

FIG. 3. Purification of the Glucosyltransferase with a Bio-Gel P-150 Column.

The enzyme from a column of DEAE Bio-Gel A was chromatographed on a column $(2.2 \times 65 \mathrm{~cm})$ of Bio-Gel P150 , and eluted with the same buffer. Fractions of $5 \mathrm{ml}$ each were collected. The void volume corresponds to tube 22. ----, protein;

- enzyme activity.

in tubes 55 95 was free from levan hydrolase. This fraction was concentrated with an ultrafiltration membrane (UK-10, Toyo Roshi Co., Tokyo), and then applied to a Bio-
Gel P-150 column (Fig. 3).

The purification processes of glucosyltransferase are summarized in Table I. The purified enzyme was obtained with a recovery of $3 \%$. The low yield of the enzyme may be partly attributed to the presence of fructosyltransferase in the crude enzyme preparation, and the measurement of reducing groups released from sucrose could not distinguish the glucosyltransferase activity from that of fructosyltransferase. The possibility of the presence of $\beta$-D-fructofuranosidase or $\alpha$-Dglucosidase in the crude enzyme remains to be clarified. The purified enzyme preparation, which contained $54 \mu \mathrm{g}$ sugar as glucose equivalent per mg protein, was free from frucosyltransferase, levan hydrolase, dextranase, and $\alpha$-D-( $1 \rightarrow 3)$-glucanase. Further purification of the enzyme on a hydroxylapatite column using linear gradient elution with phosphate buffer showed that the enzyme could be eluted with $0.15 \mathrm{~m}$ buffer, $\mathrm{pH}$ 6.8. This fraction showed a symmetrical peak of the glucosyltransferase activity, coincident with elution of the protein, but the specific activity was lower than that obtained from the Bio-Gel P-150 column. 
Table I. Purification of Glucosyltransferase

\begin{tabular}{lcccrr}
\hline \multicolumn{1}{c}{ Step } & $\begin{array}{c}\text { Total } \\
\text { volume } \\
(\mathrm{ml})\end{array}$ & $\begin{array}{c}\text { Activity } \\
\text { (units/ml) }\end{array}$ & $\begin{array}{c}\text { Specific activity } \\
\text { (units/mg protein) }\end{array}$ & $\begin{array}{c}\text { Purity } \\
(\text {-fold })\end{array}$ & $\begin{array}{c}\text { Yield } \\
(\%)\end{array}$ \\
\hline Culture filtrate & 7500 & 0.07 & 0.006 & 1 & 100 \\
Ammonium sulfate & 220 & 0.73 & 0.16 & 27 & 31 \\
Hydroxylapatite & 102 & 0.34 & 0.38 & 63 & 7 \\
DEAE Bio-Gel A & 206 & 0.10 & 0.40 & 67 & 5 \\
Bio-Gel P-150 & 120 & 0.13 & 0.52 & 87 & 3 \\
\hline
\end{tabular}

\section{Properties of the enzyme}

The glucosyltransferase eluted from the BioGel P-150 column was allowed to act on sucrose and the reaction velocity was assayed. The reaction velocity was proportional to time, up to $45 \mathrm{~min}$ when 0.005 units of enzyme was used, and to enzyme concentrations in a range of $0 \sim 0.03$ units. The reaction products were found to be a water-insoluble glucan together with fructose and glucose in a molar ratio of $1.0: 0.42 \sim 0.60$, liberated from sucrose, and also traces of reducing oligosaccharides as shown by HPLC.

The optimum $\mathrm{pH}$ of the enzyme action was 5.8 (Fig. 4). The effect of pH on the stability of the enzyme was examined after storage of the enzyme in various buffer solutions for $24 \mathrm{hr}$ at $4^{\circ} \mathrm{C}$, and then the $\mathrm{pH}$ was adjusted to 5.8 , followed by incubation with sucrose. The enzyme was stable in the range of $\mathrm{pH} 4.5$ to 8.0

The effect of temperature on the enzyme activity was examined by incubation of the enzyme at various temperatures for $10 \mathrm{~min}$. The optimum temperature of the enzyme action was shown to be $40^{\circ} \mathrm{C}$, and the enzyme was stable below $40^{\circ} \mathrm{C}$, but the activity was lost irreversibly at higher temperatures, i.e., $65 \%$ at $50^{\circ} \mathrm{C}$, and $100 \%$ at $55^{\circ} \mathrm{C}$.

The effect of substrate concentration on the enzyme activity was examined by incubation of the enzyme with several concentrations of sucrose $(0.5$ to $500 \mathrm{~mm})$ for $15 \mathrm{~min}$ at $37^{\circ} \mathrm{C}$. The apparent $K m$ value, calculated from the Lineweaver-Burk plot, was found to be $7.2 \mathrm{~mm}$ for sucrose.

The enzyme was specific to sucrose, and did not produce polysaccharide from any other

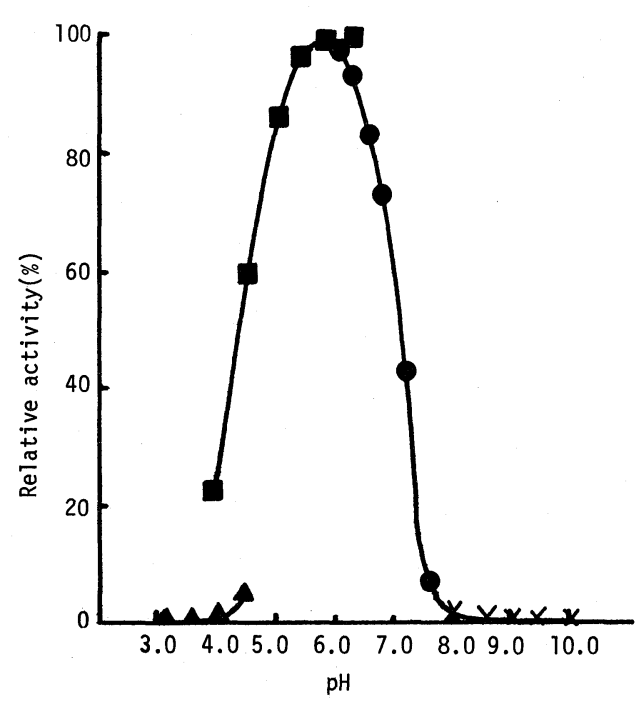

Fig. 4. Effect of $\mathrm{pH}$ on the Glucosyltransferase Activity.

Each tube contains $25 \mathrm{~mm}$ sucrose and 0.02 units of the enzyme in $0.05 \mathrm{M}$ buffers $(0.2 \mathrm{ml})$ of various pHs. After incubation for $15 \mathrm{~min}$ at $37^{\circ} \mathrm{C}$, the reducing power was measured. $\boldsymbol{\Delta}-\mathbf{\Delta}$, citrate buffer; $\mathbf{\square}-\boldsymbol{\square}$, acetate buffer; - - phosphate buffer; $\times-\times$, ammoniumammonium chloride buffer.

sugars, e.g., glucose, fructose, maltose, maltotriose, isomaltose, cellobiose, $\alpha$-methyl glucoside, $O-\alpha$-D-glucopyranosyl-( $(1 \rightarrow 3)-O-\alpha-$ D-glucopyranosyl-( $1 \rightarrow 4)$-D-glucopyranose, trehalose, turanose, raffinose, $4^{\mathrm{G}}$ - $\alpha$-glucosylsucrose, $4^{\mathrm{G}}-\alpha$-maltosylsucrose, melezitose, lactose, and melibiose. The enzyme also did not hydrolyze these sugars, so far as examined by measurement of liberated reducing groups and also by paper chromatography.

Effects of various metal ions and chemical reagents on the enzyme activity were investigated. As shown in Table II, $\mathrm{Fe}^{3+}, \mathrm{Zn}^{2+}, \mathrm{Ag}^{+}$, 
TABle II. EFFects of Metal IONS AND Chemical Reagents on the ENZYME ACTIVITY

The enzyme $(0.01$ units) was incubated in $0.05 \mathrm{M}$ acetate buffer $(0.15 \mathrm{ml}), \mathrm{pH} 5.8$, containing metal ions or chemical reagents for $5 \mathrm{~min}$ at $37^{\circ} \mathrm{C}$, and then $100 \mathrm{~mm}$ sucrose in the buffer $(0.05 \mathrm{ml})$ was added. The incubation was continued for $15 \mathrm{~min}$ at $37^{\circ} \mathrm{C}$. The reducing power was measured in each reaction mixture with correction for the effect of metal ions or chemical reagent by the Nelson-Somogyi method using standard fructose solution.

\begin{tabular}{|c|c|c|}
\hline Additives & $\begin{array}{c}\text { Final } \\
\text { concentration } \\
\text { (M) }\end{array}$ & $\begin{array}{c}\text { Activity } \\
(\%)\end{array}$ \\
\hline None & - & 100 \\
\hline $\mathrm{NaCl}$ & $10^{-3}$ & 100 \\
\hline $\mathrm{CaCl}_{2}$ & $10^{-3}$ & 128 \\
\hline $\mathrm{BaCl}_{2}$ & $10^{-3}$ & 126 \\
\hline $\mathrm{MgCl}_{2}$ & $10^{-3}$ & 100 \\
\hline $\mathrm{MnCl}_{2}$ & $10^{-3}$ & 100 \\
\hline $\mathrm{FeCl}_{2}$ & $10^{-3}$ & 100 \\
\hline $\mathrm{FeCl}_{3}$ & $10^{-3}$ & 44 \\
\hline $\mathrm{ZnCl}_{2}$ & $10^{-3}$ & 56 \\
\hline $\mathrm{CH}_{3} \mathrm{COOAg}$ & $10^{-3}$ & 14 \\
\hline $\mathrm{CuCl}_{2}$ & $10^{-3}$ & 0 \\
\hline $\mathrm{HgCl}_{2}$ & $10^{-3}$ & 0 \\
\hline L-Cysteine & $10^{-3}$ & 95 \\
\hline DTT & $10^{-3}$ & 93 \\
\hline 2-ME & $10^{-3}$ & 105 \\
\hline РСМВ & $10^{-4}$ & 74 \\
\hline $\mathrm{ICH}_{2} \mathrm{COOH}$ & $10^{-3}$ & 93 \\
\hline SDS & $10^{-3}$ & 0 \\
\hline Triton X-100 & $0.01 \%{ }^{a}$ & 107 \\
\hline Urea & $10^{-1}$ & 100 \\
\hline EDTA & $10^{-3}$ & 74 \\
\hline
\end{tabular}

a Expressed as \%. DTT, dithiothreitol; 2-ME, 2mercaptoethanol; PCMB, $p$-chloromercuribenzoate; SDS, sodium dodecylsulfate; EDTA, ethylenediamine tetra-acetate.

$\mathrm{Cu}^{2+}$ and $\mathrm{Hg}^{2+}$ were strongly inhibitory toward the enzyme action at $10^{-3} \mathrm{M}$. PCMB, EDTA and SDS also inhibited the enzyme activity.

\section{Structure of the water-insoluble glucans}

The glucosidic linkages of the waterinsoluble glucans prepared from sucrose by incubation with glucosyltransferase, obtained at different purification steps, were examined. The enzyme preparations were incubated with $300 \mathrm{~mm}$ sucrose at different $\mathrm{pHs}$, for $48 \mathrm{hr}$ at $37^{\circ} \mathrm{C}$. There was no water-soluble polysaccharide in each reaction mixture, except for the crude enzyme obtained from the ammonium sulfate fractionation. The waterinsoluble glucan in each reaction mixture was purified, methylated, and the hydrolysis products were examined by GLC. The results, shown in Table III, indicate that the proportion of $\alpha-(1 \rightarrow 3)$-D-glucosidic linkages in the glucan, synthesized at $\mathrm{pH} 6.8$, was $87 \sim 90 \%$, while, the glucan synthesized by the enzyme from the Bio-Gel P-150 column at a lower $\mathrm{pH}$ ( $\mathrm{pH} 5.0)$ contained a lower proportion $(80 \%)$ of $(1 \rightarrow 3)$-D-glucosidic linkages, the same amount as that of the extracellular glucan. The yield of the glucans (e.g., $74 \mathrm{mg}$ in the case of the Bio-Gel P-150 enzyme, at pH 5.8) was much lower than that expected from the release of reducing sugars $(645 \mathrm{mg}$ as fructose; molar ratio of fructose and glucose, $1.0: 0.57$ ).

Effects of polysaccharides on the enzyme activity and on the production of the waterinsoluble glucans

The effects of various polysaccharides on the glucosyltransferase action were examined by incubation of the enzyme with sucrose in the presence of dextran, $\alpha$-D- $(1 \rightarrow 3)$-glucan or fruc$\tan$ in concentrations of $12.5 \mu \mathrm{g}$ to $2.5 \mathrm{mg}$ per $\mathrm{ml}$. As shown in Fig. 5, the enzyme activity was increased by the addition of dextran and the extracellular water-insoluble glucan. Among these polysaccharides the high molecular weight dextran (MW $3 \times 10^{6}$ ) was most effective for stimulating the activity, 2-fold at $500 \mu \mathrm{g}$ of dextran per ml. However, no effect was observed with other polysaccharides, i.e., the fructan of $S$. salivarius HHT, soluble starch, pullulan and cellulose.

When the enzyme was incubated with $50 \mathrm{~mm}$ sucrose in the presence of dextran (MW $1 \times 10^{4}, 500 \mu \mathrm{g}$ per $\left.\mathrm{ml}\right)$, the yield of the waterinsoluble glucan increased 7 -fold (Fig. 6). As to the stimulation of the synthesis of the glucan with dextran, the amount of the released reducing sugar at the final reaction stage was assayed. The results showed that the increase in the liberation of reducing sugars from 
Table III. Methylation Analyses of the Water-insoluble Glucans Produced by Glucosyltransferase

The production of the water-insoluble glucans was conducted by the incubation of the enzymes of different purification steps (The ammonium sulfate precipitated enzyme, 4.6 units, hydroxylapatite enzyme, 2.0 units, and Bio-Gel enzyme 2.0 units, respectively) with $300 \mathrm{~mm}$ sucrose at $\mathrm{pH} 6.8, \mathrm{pH}, 5.8(50 \mathrm{ml}, 0.05 \mathrm{~m}$ phosphate buffers), and pH $5.0\left(50 \mathrm{ml}, 0.05 \mathrm{M}\right.$ acetate buffer) for $48 \mathrm{hr}$ at $37^{\circ} \mathrm{C}$.

\begin{tabular}{|c|c|c|c|c|c|c|}
\hline & \multirow{3}{*}{$\begin{array}{l}\text { Extracellular } \\
\text { glucan }\end{array}$} & \multicolumn{5}{|c|}{ Enzymatically synthesized glucans } \\
\hline & & \multirow{2}{*}{$\begin{array}{c}\text { Ammonium } \\
\text { sulfate } \\
\text { pH } 6.8\end{array}$} & \multirow{2}{*}{$\begin{array}{l}\text { Hydroxyl } \\
\text { apatite } \\
\text { pH } 6.8\end{array}$} & \multicolumn{3}{|c|}{ Bio-Gel P-150 } \\
\hline & & & & $\mathrm{pH} 5.0$ & pH 5.8 & pH 6.8 \\
\hline $\begin{array}{l}\text { Yield of glucan } \\
\text { (dry weight, mg) }\end{array}$ & & 31 & 51 & 32 & 74 & 70 \\
\hline \multicolumn{7}{|l|}{$O$-Methyl-D-glucose $(\%)$} \\
\hline 2,3,4,6-tetra- & 3.5 & 1.7 & 2.6 & 2.4 & 1.2 & 1.2 \\
\hline $2,4,6$-tri- & 80.4 & 87.8 & 87.0 & 80.4 & 89.5 & 89.6 \\
\hline $\begin{array}{l}\text { 2,3,4-tri- and/or } \\
2,3,6 \text {-tri- }\end{array}$ & 12.2 & 8.3 & 7.4 & 15.1 & 8.4 & 8.3 \\
\hline 2,4-di- & 3.9 & 2.2 & 3.0 & 2.1 & 0.9 & 0.9 \\
\hline
\end{tabular}

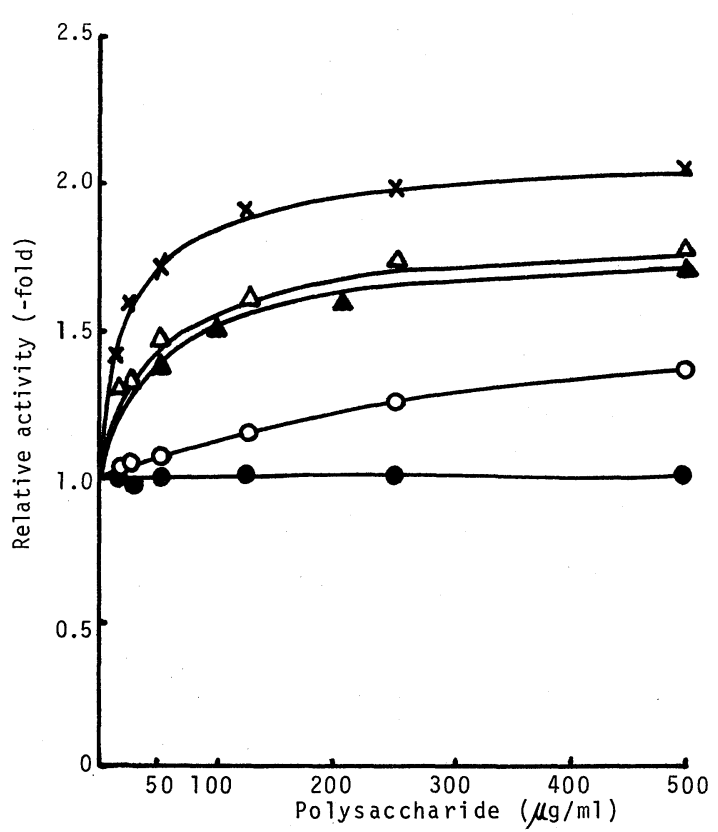

Fig. 5. Effect of Various Polysaccharides on the Initial Velocity of the Glucosyltransferase.

After the enzyme (0.01 units) was incubated with different concentrations of polysaccharides in $0.05 \mathrm{M}$ phosphate buffer $(0.15 \mathrm{ml})$, pH 5.8, for $5 \mathrm{~min}$ at $37^{\circ} \mathrm{C}, 100 \mathrm{~mm}$ sucrose in the same buffer $(0.05 \mathrm{ml})$ was added. The incubation was continued for $15 \mathrm{~min}$ at $37^{\circ} \mathrm{C}$. Reducing power was measured and expressed relative to a control. $\times-\times$, dextran (MW $3 \times 10^{6}$ ); $\triangle-\triangle$, dextran (MW $1.1 \times 10^{5}$ ); $\mathbf{\Delta}-\boldsymbol{\Delta}$, dextran $\left(\mathrm{MW} 1 \times 10^{4}\right) ; \mathrm{O}-\mathrm{O}$, extracellular water-insoluble glucan; $-\mathbf{O}$, extracellular watersoluble fructan.

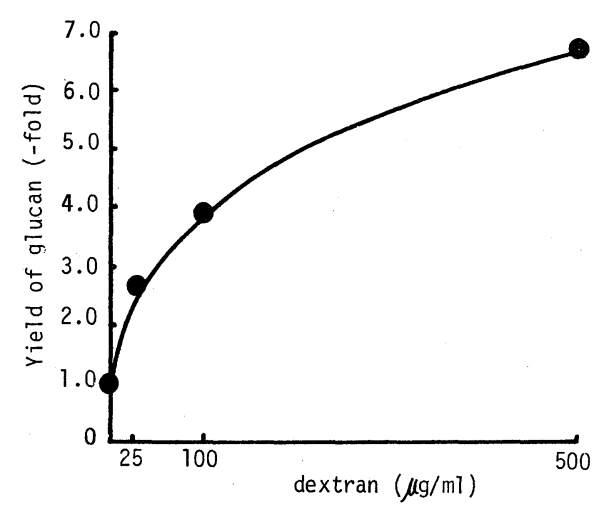

FIG. 6. Effects of Dextran (MW, $\left.1 \times 10^{4}\right)$ on the Synthesis of the Water-insoluble Glucan.

The enzyme (1.4 units) was incubated with $50 \mathrm{~mm}$ sucrose in $0.05 \mathrm{M}$ phosphate buffer $(50 \mathrm{ml}), \mathrm{pH} 5.8$, in the presence of different concentrations of the dextran for $48 \mathrm{hr}$ at $37^{\circ} \mathrm{C}$. The glucan in each reaction mixture was collected, dried, weighed and the yield is expressed relative to that in the absence of dextran (yield, $21.7 \mathrm{mg}$ ).

sucrose gives almost the same value as those found at the initial velocity (Fig. 5), but, the ratio of glucose to fructose in the reaction mixture was suppressed to $0.60,0.56,0.50$, and 0.33 at concentrations of dextran of $0,25,100$, $500 \mu \mathrm{g}$ per $\mathrm{ml}$, respectively. This suggests that the low molecular weight dextran acts as an effective glucosyl-acceptor for the glucan synthesis. 
TABle IV. EFFects of VARIOUS Sugars ON THE YIELD OF THE WATERINSOLUBLE GLUCAN

The enzyme (1.5 units) was incubated with $78 \mathrm{~mm}$ sucrose in $0.05 \mathrm{~m}$ phosphate buffer $(50 \mathrm{ml}), \mathrm{pH} 5.8$, in the presence of each sugar, equal mole ratio to sucrose, for $48 \mathrm{hr}$ at $37^{\circ} \mathrm{C}$. The weight of the glucan is expressed relative to that in the presence of sucrose only $(45 \mathrm{mg})$.

\begin{tabular}{lc}
\hline \multicolumn{1}{c}{ Sugar } & $\begin{array}{c}\text { Yield of glucan } \\
\text { (-fold) }\end{array}$ \\
\hline None & 1.00 \\
Glucose & 1.00 \\
Fructose & 0.90 \\
Maltose & 0.34 \\
Cellobiose & 1.27 \\
Maltotriose & 0.91 \\
Glc $p 1 \rightarrow 3$ Glc $p 1 \rightarrow 4$ Glc $p^{*}$ & 0.90 \\
$\alpha$-Methyl glucoside & 1.14 \\
Trehalose & 0.90 \\
Turanose & 1.06 \\
Raffinose & 1.06 \\
Melezitose & 1.02 \\
Lactose & 1.12 \\
Melibiose & 1.00 \\
\hline
\end{tabular}

* $O$ - $\alpha$-D-glucopyranosyl- $(1 \rightarrow 3)-O$ - $\alpha$-D-glucopyranosyl-( $1 \rightarrow 4)$-D-glucopyranose.

Effects of mono- and oligosaccharides on the enzyme action

Effects of various mono- and oligosaccharides on the yield of the water-insoluble glucan were examined by incubation of the enzyme (1.5 units) with $78 \mathrm{~mm}$ sucrose in the presence of equal molar proportions of monoand oligosaccharides. As listed in Table IV, the yield of the glucan was decreased remarkably by the addition of maltose. No water-soluble polysaccharide was formed. Isomaltose also showed inhibition of the glucan synthesis. Other mono- and oligosaccharides had little or no effect on the yield of the glucan. The structure of the glucan formed in the presence of maltose was examined. Methylation followed by acid hydrolysis of this glucan yielded 2,3,4,6-tetra-, 2,4,6-tri-, 2,3,6-tri- and/or 2,3,4tri, and 2,4-di- $O$-methyl-D-glucose in molar proportions of $1: 87: 11: 1$, as analyzed by GLC. These proportions are close to $2: 88: 8: 2$, obtained in the case of glucan synthesized in the absence of maltose. These

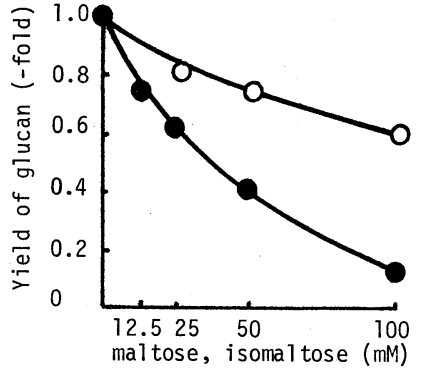

Fig. 7. Effects of Maltose and Isomaltose on the Yield of the Water-insoluble Glucan.

The enzyme (1.4 units) was incubated with $50 \mathrm{~mm}$ sucrose in $0.05 \mathrm{M}$ phosphate buffer $(50 \mathrm{ml}), \mathrm{pH} 5.8$, containing different concentrations of maltose (-) or isomaltose $(\bigcirc-\bigcirc)$ for $48 \mathrm{hr}$ at $37^{\circ} \mathrm{C}$. The yield of the glucan is expressed relative to a control $(21.7 \mathrm{mg})$.

results clearly indicate that the addition of maltose does not alter the structural features of the glucan.

The effects of the concentration of maltose, and also isomaltose, on the yield of the glucan are compared in Fig. 7. The yield of the glucan decreased with increasing maltose concentration. The presence of two moles of maltose per mole of sucrose resulted in $88 \%$ inhibition of synthesis of the glucan. Isomaltose exibits lower inhibition, compared with that of maltose. The reaction products at the final stages of the incubations were examined by HPLC. The amount of the reducing monosaccharides was increased 2.2-fold in the presence of two molar proportions of maltose per sucrose, compared to that of the absence of maltose. The proportion of glucose in the reaction mixture was decreased gradually by the addition of maltose; only fructose was detected in the presence of two moles of maltose per sucrose. However, the amount of the liberated reducing sugars in the presence of isomaltose was found to be almost constant.

During incubation of the enzyme with sucrose in the presence of maltose, significant amounts of oligosaccharides were formed. In order to characterize these oligosaccharides, sucrose $(50 \mathrm{~mm}, 130 \mathrm{ml})$ was incubated in the presence of maltose $(50 \mathrm{~mm})$. Sugars $(4.1 \mathrm{~g})$ in the supernatant were fractionated on a charcoal column $(2.2 \times 45 \mathrm{~cm}$, Wako Pure 
Chemical Ind., Osaka). After washing the column with distilled water (1.5 liters), oligosaccharides were successively eluted with 1 liter each of $7.5,12,20,25$ and warm $50 \%$ aqueous ethanol at room temperature, and appropriate eluates, after examination by paper chromatography, were combined and the oligosaccharide fraction was further purified by preparative paper chromatography.

\section{$O-\alpha-\mathrm{D}-G l u c o p y r a n o s y l-(1 \rightarrow 6)-O-\alpha-\mathrm{D}-$ glucopyranosyl-( $1 \rightarrow 4)$-D-glucopyranose (panose)}

A trisaccharide component (602 mg), which was the major saccharide produced in the presence of maltose, had DP 2.9, $R_{\mathrm{GLC}} 0.38$, $M_{\mathrm{GLC}} 0.25$ and $[\alpha]_{\mathrm{D}}+154^{\circ}$ (c 0.8 , water). Methylation and acid hydrolysis of this trisaccharide showed the presence of 2,3,4,6tetra- and 2,3,6-tri and/or 2,3,4-tri- $O$-methylD-glucose in the molar ratio of $1.00: 1.90$, when analyzed by GLC as the alditol acetates. GLC analysis after conversion to methyl glucosides, showed the presence of both 2,3,6and 2,3,4-tri- $O$-methyl-D-glucose, approximately in an equal molar ratio. Partial acid hydrolysis of the trisaccharide yielded glucose, maltose and isomaltose, as revealed by paper chromatography. When the glucoamylase acted on the trisaccharide, glucose and maltose were detected in the digestion process, and at the final stage only glucose was formed. From the above results, this trisaccharide was identified as panose.

$O-\alpha-\mathrm{D}-$ Glucopyranosyl- $(1 \rightarrow 3)-O-\alpha-\mathrm{D}-$ glucopyranosyl-( $1 \rightarrow 4)$-D-glucopyranose

The other trisaccharide component $(60 \mathrm{mg})$, having $D P 3.1$, showed $M_{\mathrm{GLC}} 0.26$ and $R_{\mathrm{GLC}}$ 0.48 , which appeared to be slightly higher than those of maltotriose. Methylation followed by acid hydrolysis of the trisaccharide revealed the presence of 2,3,4,6-tetra-, 2,4,6-tri- and 2,3,6-tri- $O$-methyl-D-glucose in the molar ratio of $1.00: 0.90: 1.06$. The glucoamylase degradation of the trisaccharide component showed glucose, maltose and the unreacted trisaccharide, and at the final stage only glu- cose and the unreacted trisaccharide were detected. When the component was reacted with $\alpha$-D-glucosidase, glucose and maltose were yielded, in addition to the unreacted trisaccharide. From these results, the trisaccharide was characterized as $O-\alpha$-D-glucopyranosyl$(1 \rightarrow 3)-O$ - $\alpha$-D-glucopyranosyl-( $1 \rightarrow 4)$-D-glucopyranose. Inspection of methylation data and the partial digestability with glucoamylase suggest that a trace amount of maltotriose is also contained in this component.

$O-\alpha-\mathrm{D}-$ Glucopyranosyl-( $1 \rightarrow 6)-O-\alpha-\mathrm{D}-$ glucopyranosyl-( $1 \rightarrow 6)$-O- $\alpha-\mathrm{D}-$ glucopyranosyl( $1 \rightarrow 4$ )-D-glucopyranose

A tetrasaccharide component $(17 \mathrm{mg})$ gave DP 3.8, $R_{\mathrm{GLC}} 0.16, M_{\mathrm{GLC}} 0.25$ and $[\alpha]_{\mathrm{D}}+155^{\circ}$ (c 0.7 , water). Methylation analysis of the compound showed the presence of 2,3,4,6tetra- 2,3,6-tri- and/or 2,3,4-tri- $O$-methyl-Dglucose in the molar ratio of $1.00: 2.97$. The identification of both 2,3,6- and 2,3,4-tri-Omethyl-D-glucose (molar ratio, 1:2) was per formed in the same manner as for panose. Glucoamylase hydrolysis of the compound gave glucose, maltose, panose and the unreacted tetrasaccharide, and at the final stage only glucose was detected. From the above results, this tetrasaccharide was identified as $O$ - $\alpha$-D-glucopyranosyl-( $1 \rightarrow 6)-O$ - $\alpha$-D-glucopyranosyl- $(1 \rightarrow 6)-O$ - $\alpha$-D-glucopyranosyl-( $1 \rightarrow 4)$ D-glucopyranose.

\section{DISCUSSION}

Glucosyltransferases have been purified from cultures of several cariogenic Streptococci, such as $S$. mutans OMZ176, ${ }^{1,6)}$ HS$6,{ }^{3,19)} 6715,{ }^{4,20} \quad 6715-49,{ }^{21)} \mathrm{K} 1-\mathrm{R},{ }^{5)}$ and $S$. sanguis $804,{ }^{2}$ and their enzymic properties have been examined. These enzyme preparations produce water-insoluble glucans exhibiting differences in the relative proportions of $\alpha$ $(1 \rightarrow 3)$ - and $(1 \rightarrow 6)$-D-glucosidic linkages. $S$. salivarius HHT produces extracellularly a water-insoluble glucan together with a large amount of a water-soluble fructan. ${ }^{12)}$ As reported in the previous paper, ${ }^{7)}$ the water- 
insoluble glucan contains a high proportion of $\alpha-(1 \rightarrow 3)$-D-glucosidic linkage $(80 \%)$, constituting mainly a long consecutive backbone chain with a slight degree of branching. The short side chains, attached at the 0-6 position of the $(1 \rightarrow 3)$-linked D-glucose residues, consist of $\alpha-(1 \rightarrow 6)-$ and $\alpha-(1 \rightarrow 4)$ - together with a trace of $\alpha-(1 \rightarrow 3)$-linked $D$-glucosyl residues. In the present study, the incubation of the glucosyltransferase purified from the culture filtrate of HHT with sucrose at $\mathrm{pH} 6.8$ or 5.8 resulted in the formation of a water-insoluble glucan containing $90 \%$ of $\alpha-(1 \rightarrow 3)$-D-glucosidic linkage, a much higher proportion compared with that of the extracellular glucan. However, this glucan was still slightly branched with non- $(1 \rightarrow 3)$ linked D-glucose residues.

It may be noteworthy that the waterinsoluble glucan synthesized at a low $\mathrm{pH}, \mathrm{pH}$ 5.0 , possesses a rather lower proportion of $\alpha$ $(1 \rightarrow 3)$-D-glucosidic linkage $(80 \%)$. In connection with this, Gibbons et al. ${ }^{22)}$ reported that the proportions of water-insoluble and -soluble glucans produced with crude enzyme of $S$. mutans GS-5 depend on the $\mathrm{pH}$ during the incubation. Guggenheim et al. and Newbrun et $a l^{1,2,23)}$ showed that in the cases of $S$. mutans OMZ176 and S. sanguis 804 the biosynthesis of water-insoluble glucans containing different proportions of $\alpha-(1 \rightarrow 3)$ - and non$(1 \rightarrow 3)$-D- glucosidic linkages may involve several types of glucosyltransferase. Since the present enzyme preparation isolated by several purification steps consists most likely of only one specific glucosyltransferase, there is a possibility that there is a low but significant difference in the proportions of the $(1 \rightarrow 3)$ - and non- $(1 \rightarrow 3)$-linkages in the present glucan preparations synthesized at different $\mathrm{pHs}$ due to $\mathrm{pH}$-dependency of the branch formation by the same glucosyltransferase. Some of the $\alpha$ $(1 \rightarrow 3)$-linked D-glucose residues in the backbone chain would act as glucosyl acceptors, but, more detailed studies on the specificity of the glucosyltransferase are necessary for resolving this interesting problem.

The lower yield of the water-insoluble glucan than that expected from the liberation of reducing monosaccharides may be attributed to the low efficiency of the action of glucosyltransfer on the glucan molecule. The liberation of free glucose in the reaction mixture may be due to the hydrolysis of sucrose by the glucosyltransferase action, as reported in the cases of $S$. mutans HS- $6^{3)}$ and $6715 .^{20)}$ The possibility of the presence of $\beta$-D-fructofuranosidase in the purified enzyme preparation may be ruled out, because raffinose and other oligosaccharides containing $\beta$-D-fructofuranosidic linkages were not susceptible to the enzyme.

Examination of the effect of some polysaccharides on the enzymic synthesis of $\alpha-D-$ $(1 \rightarrow 3)$-glucan indicates that the presence of dextran stimulates the glucosyl-transfer activity. This phenomenon has been reported in the cases of several Streptococci, e.g., S. mutans HS-6, ${ }^{3)} 6715,{ }^{4,24)}$ OMZ176, ${ }^{6,25)}$ and $S$. sanguis $804 .^{26)}$ It is also known that the low molecular weight dextran stimulates the synthesis of water-soluble glucan with concomitant suppression of the production of insoluble glucan in enzyme systems possibly containing several types of glucosyltransferases. ${ }^{22,25,27,28)}$ The synthesis of the insoluble glucan with the present purified enzyme of HHT was accelerated by the addition of dextran, as in the case of OMZ176. ${ }^{6)}$ The fact that the release of glucose was decreased by increasing the water-soluble dextran, added to the reaction mixture, indicates that the dextran molecules may act as efficient glucosylacceptors, as reported by Fukui et al. ${ }^{3)}$

The transfer of D-glucosyl residues from sucrose to mono- and oligosaccharide acceptors by glucosyltransferases has extensively been investigated. ${ }^{29 \sim 31)}$ The effect of maltose as the glucosyl-acceptor in the glucosyltransferase action on sucrose has previously been shown in the case of glucosyltransferases of Leuconostoc mesenteroides NRRL B-512 ${ }^{29)}$ which catalyze synthesis of dextran, and of Streptococci. ${ }^{30)}$ The present results show that maltose strongly inhibits the formation of the insoluble glucan. Simultaneously, the presence of maltose stimulates the glucosyl-transfer ac- 
tivity by increasing the ratio of this sugar to sucrose, with concomitant formation of panose, and other oligosaccharides such as $O$ - $\alpha$-D-glucopyranosyl- $(1 \rightarrow 3)-O$ - $\alpha$-D-glucopyranosyl-( $1 \rightarrow 4)$-D-glucopyranose, maltotriose, and $O$ - $\alpha$-D-glucopyranosyl-( $1 \rightarrow 6)-O$ - $\alpha$-D-glucopyranosyl-( $1 \rightarrow 6)-O$ - $\alpha$-D-glucopyranosyl$(1 \rightarrow 4)$-D-glucopyranose. This indicates that the glucosyl-transfer reaction occurs on the $0-6$ position as well as the $0-3$ and even $0-4$ positions of the non-reducing glucosyl moiety of maltose, instead of glucosyl-transfer to the endogenous glucan molecule. Elucidation of the specificities of transfer actions of this enzyme, including the branching formation on $\alpha-(1 \rightarrow 3)$-D-glucan, must await further investigation.

Acknowledgments. We thank Mr. H. Miyaji, Meito Sangyo Co., for the supply of isomaltose and dextrans, and Dr. K. Sugimoto, Hayashibara Biochemical Lab., for the supply of some oligosaccharide specimens. We also thank Dr. Y. Tsujisaka, Osaka Municipal Technical Research Institute, for the supply of panose.

\section{REFERENCES}

1) B. Guggenheim and E. Newbrun, Helv. Odont. Acta, 13, 84 (1969).

2) E. Newbrun, Caries Res., 5, 124 (1971).

3) K. Fukui, Y. Fukui and T. Moriyama, J. Bacteriol., 118, 796 (1974).

4) A. M. Chludzinski, G. R. Germaine and C. F. Schachtele, J. Bacteriol., 118, 1 (1974).

5) G. J. Walker and M. D. Hare, Carbohydr. Res., 58, 415 (1977).

6) M. D. Hare, S. Svensson and G. J. Walker, Carbohydr. Res., 66, 245 (1978).

7) Y. Tsumuraya and A. Misaki, Carbohydr. Res., 74, 217 (1979).

8) J. M. Jablon and D. D. Zinner, J. Bacteriol., 92, 1590
(1966).

9) S. Kitahata, Ph.D thesis, Osaka Municipal Technical Research Institute (1977).

10) Y. Tsumuraya and A. Misaki, J. Appl. Biochem., 1, 235 (1979).

11) N. Nelson, J. Biol. Chem., 153, 375 (1944); M. Somogyi, J. Biol. Chem., 195, 19 (1952).

12) S. Ebisu, K. Kato, S. Kotani and A. Misaki, J. Biochem., 78, 879 (1975).

13) M. Dubois, K. A. Gilles, J. K. Hamilton, P. A. Rebers and F. Smith, Anal. Chem., 28, 350 (1956).

14) T. E. Timell, Svensk Papperstid., 63, 668 (1960).

15) O. H. Lowry, N. J. Rosebrough, A. L. Farr and R. J. Randall, J. Biol. Chem., 193, 265 (1951).

16) W. E. Trevelyan, D. P. Procter and J. S. Harrison, Nature, 166, 444 (1950).

17) Y. Yamada, M. Hisamatsu and M. Taki, $J$. Chromatogr., 103, 390 (1975).

18) S. Hakomori, J. Biochem., 55, 205 (1964).

19) H. Mukasa and H. D. Slade, Infect. Immun., 10, 1135 (1974).

20) J. E. Ciardi, A. J. Beaman and C. L. Wittenberger, Infect. Immun., 18, 237 (1977).

21) M. M. McCabe and E. E. Smith, Infect. Immun., 16, 760 (1977).

22) R. J. Gibbons and M. Nygaard, Arch. Oral Biol., 13, 1249 (1968).

23) M. Ceska, K. Granath, B. Norrman and B. Guggenheim, Acta Chem. Scand., 26, 2223 (1972).

24) G. R. Germaine, A. M. Chludzinski and C. F. Schachtele, J. Bacteriol., 120, 287 (1974).

25) J. F. Robyt and A. J. Corrigan, Arch. Biochem. Biophys., 183, 726 (1977).

26) J. Carlsson, E. Newbrun and B. Krasse, Arch. Oral Biol., 14, 469 (1969).

27) T. J. Montville, C. L. Cooney and A. J. Sinskey, Infect. Immun., 18, 629 (1977).

28) M. M. McCabe and E. E. Smith, Infect. Immun., 7, 829 (1973).

29) H. J. Koepsell, H. M. Tsuchiya, N. N. Hellman, A. Kazenko, C. A. Hoffman, E. S. Sharpe and R. W. Jackson, J. Biol. Chem., 200, 793 (1953).

30) G. J. Walker, J. Dent. Res., 51, 409 (1972).

31) G. J. Walker, Carbohydr. Res. 82, 404 (1980). 